\title{
CRITERII DE EVALUARE A TEZELOR DE DOCTORAT Anca ROZOREA*
}

\section{Abstract}

In the article are presented research work carried out under the project POSDRU ,The innovation and the development of doctoral curriculum from the perspective of training and assessment of research competences; correlations with the mechanisms of quality assurance" (Contract: POSDRUV1.5V2IVGV 36046), in order to design and validation of criteria for evaluation of Doctoral Theses.

A cross-check of the results obtained enabled the achievement of Grid for assessment of Doctoral Thesis, synthetic and operational tool, that can contribute to the theoretical and conceptual unity for the evaluation of the Doctoral Thesis and for increase its objectivity degree.

Cuvinte cheie: reforma Şcolii Doctorale, Teză de Doctorat, criterii de evaluare

Permanenta procesului de reformă în educaţie implică şi reformarea studiilor doctorale, doctoratul reprezentând, pentru cele mai multe ţări din Europa, ciclul trei de învăţământ superior (în conformitate cu Procesul Bologna), „postgraduate education" sau „research training", finalizat prin diplomă de educaţie opţională, recunoscută internaţional, care certifică o calificare profesională superioară pe piał̧a muncii, în cercetare şi în lumea academică.

Pe coordonate istorice, doctoratul s-a născut în universitătile europene medievale, el certificând dreptul de predare în universitate; în aceste universităti, titlul a fost mai întâi conferit numai în filosofie, fiind 0 recunoaştere a dreptului de a fi "profesor de filosofie".

Denumirea latinã originală era de „Philosophiae Doctor“ (PhD), denumire consacrată ulterior, mai ales în tările anglo-saxone, şi pentru alte discipline.

Doctoratul modern a apănut în Germania secolului al XIX-lea, prin concepţia lui Wilhelm von Humboldt despre universitate, unde a fost consacrat, către sfärşitul secolului al XIX-lea şi începutul secolului al XX-lea, răspândindu-se nu numai în tările nord-americane, ci în aproape toate universităţile europene, pentru a deveni, apoi, eminamente european (de exemplu, primul doctorat modern este introdus în Marea Britanie, in 1917 de către Universitatea din Oxford; primul doctorat din România este susłinut în

* Anca ROzOREA is an associate professor PhD at the Faculty of Psychology and Sciences of Education, University of Bucharest. E-mail: anca rozorea@yahoo.com. 
iunie 1905 de Ion Petrovici, la Universitatea din Bucureşti, cu tema „Paralelismul psiho-fizic“.

După anul 2000, doctoratul european s-a afirmat ca domeniu al prospectării şi schimbării permanente, titlul de "doctor în..." fiind cea mai înaltă calificare academică pe care o universitate o poate conferi, iar doctoratul, al treilea şi ultimul ciclu de studii universitare.

Având exemplul SUA şi al Japoniei in producerea de doctorate academice şi vocaţionale, Europa devine tot mai competitivă pe plan mondial, mai ales ca urmare a influentei Procesului Bologna, prin:

- mărirea potenţialului universităților de a accentua cercetarea axatã pe excelențã şi inovaţie

- producerea unui Spaţiu European al Învătământului Superior care să elaboreze un cadru general de calificări, compatibile şi comparabile pe plan european şi extra european

- producerea unui Spaţiu European al Cercetării inter, multi şi transdisciplinare, care sã includă şi să valorifice diversitatea şi mobilitatea interculturală în ştiință, cercetare şi practică

- pregătirea de specialişti, cercetători şi creatori, în toate domeniile, capabili să poată da răspuns la toate provocările societătii bazate pe cunoaştere, dezvoltare, schimbare, precum şi la toate problemele existenţei umane

- dezvoltarea unor relaţii cât mai strânse şi armonioase între învăţare, cercetare şi inovare socială, cognitivă sau tehnologică, între cercetarea academică şi cerinţele unei economii a informaţiei, cunoaşterii şi inovaţiei

- dezvoltarea potenţialului antreprenorial al conducătorilor de doctorat, care să treacă dincolo de atragerea de cât mai mulţi doctoranzi, eventual cu taxe, spre valorificarea cunoaşterii şi expertizei în acțiuni de transfer cognitiv şi tehnologic.

- formarea doctoranzilor atât în spiritul competențelor academice, cât şi al performării unor competențe manageriale, de comunicare şi de orientare cắtre economia reală.

În Comunicatul Bergen (mai 2005) al miniştrilor responsabili de învățământul superior din țările membre ale Procesului Bologna, doctoratul este instituit ca acel ciclu universitar care se realizează în forma ,învătării prin cercetare" după ciclul de masterat.

Se relevă importanţa doctoratului pentru reforma în educaţie, dar şi faptul cå progresul cunoaşterii, prin cercetarea originală, reprezintă componenta cheie a doctoratului şi se fac recomandări privind dezvoltarea de programe doctorale structurate şi interdisciplinare, cu evaluări transparente şi cu o durata medie de 3-4 ani de studiu full time, care să formeze abilităţi transferabile, adaptate la noile nevoi ale pieței muncii; de asemenea, in acest document este 
stabilit şi Cadrul European de Calificări în Învătământul Superior; în acest sens, „calificările de nivel doctoral trebuie să fie pe deplin aliniate cu cadrul general al calificărilor din Aria Europeană a Învățământului Superior (European Higher Education Area - EHEA), folosind o abordare orientată spre rezultat. Componenta centrală a pregătirii doctorale constă în avansul cunoaşterii prin cercetare originală“".

Pe planul educaţiei universitare, datorită orientārii tot mai pregnante a dezvoltării sociale către realizarea unei economii bazate pe transferuri cognitive şi de inovaţii tehnologice, a apărut necesitatea creşterii numănului de inovatori şi de ,manageri ai cunoaşterii" (clasicii „doctori în ştiințe").

Noile politici universitare şi ale cercetării consideră doctoratul 0 referinţă esenţială pentru creşterea competitivităţii cercetării şi a impactului acesteia asupra dezvoltării economice şi culturale.

Prin Comunicatul Londra (2007) se lansează o nouă viziune referitoare la evoluţia studiilor doctorale, accentuându-se nevoia de a îmbunătăţi statusul, finanţarea şi oportunităţile de carieră ale tânărului cercetător, de a dezvolta strategii şi politici educaţionale care să includă în mod explicit programele doctorale de asigurare a calităţii, conform Registrului European al Asigurării Calității pentru Învățământul Superior.

Cele 10 Principii Salzburg din documentul elaborat de EUA European University Association (Salzburg, 2007) au contribuit la realizarea unei viziuni comprehensive, consensuale şi unitare asupra doctoratului.

Comunicatul Leuven (2009) accentuează imperativul educaţiei de a promova inovaţia şi creativitatea în societate şi de a forma specialişti cu competenţe pentru cariera academică şi de cercetare.

Descriptorii Dublin pentru programele doctorale, folosit̨i la nivel naţional şi instituţional pentru armonizarea celor 3 cicluri ale învăţământului superior, corelaţi cu rezultatele proiectului Tuning Education Structures in Europe, demarat în anul 2000 sub egida Programului Lifelong Leaming al Comisiei Europene şi axat pe identificarea corespondențelor între diverse arii de cunoaştere (discipline), au contribuit la articularea obiectivelor Procesului Bologna cu cele din Strategia Lisabona.

Eforturile Uniunii şi Comisiei Europene în domeniul impulsionării dezvoltării Spaţiului European al Cercetării s-au finalizat printr-o serie de documente şi programe importante pentru reformarea educaţiei doctorale (European Charter for Researchers and the Code of Conduct for the Recruitment of Researchers, 2005, The European research Area: New Perspectives. Green paper, EC, 2007, Programul Erasmus Mundus II, axat pe programe doctorale (2009-2013), The European Research Framework Programme).

Doctoratul trebuie să satisfacă coordonatele educaţiei pentru excelenţă, ale diversităţii, ale exigențelor societăţii cunoaşterii, ale educaţiei permanente, ale eficienţei pe piaţa muncii, ale centrảrii pe student şi pe dezvoltarea sa 
personală, la imperativele cercetării interdisciplinare, transdisciplinare, fără a elimina ultra specializarea şi cooperarea.

Principiile şi direcțiile generale nu trebuie să excludă, însă, nici dezideratele şi tendințele specifice ale reformei naționale concrete a studiilor doctorale.

\begin{tabular}{|c|c|}
\hline $\begin{array}{l}\text { Tendinţe generale privind } \\
\text { organizarea doctoratului }\end{array}$ & $\begin{array}{l}\text { Tendințe specifice privind } \\
\text { organizarea doctoratului }\end{array}$ \\
\hline $\begin{array}{l}\text { - Nevoia de colaborare în contextul } \\
\text { globalizării lumii, pe toate } \\
\text { planurile, generează şi necesitatea } \\
\text { consensului în dezvoltarea } \\
\text { studiilor doctorale (aspecte } \\
\text { conceptuale, direcţii de evoluţie } \\
\text { aspecte formale, aspecte } \\
\text { instituționale etc.) } \\
\text { - Creşterea, dar şi diversificarea } \\
\text { numărului de doctorate, realizate } \\
\text { ca răspunsuri comparabile la } \\
\text { diversitatea problemelor cognitive } \\
\text { şi epistemologice ale societăţii } \\
\text { actuale } \\
\text { - Doctoratul nu mai este considerat } \\
\text { doar o opțiune personală de } \\
\text { continuare a studiilor academice, el } \\
\text { devenind o experiență } \\
\text { profesională care implică } \\
\text { programe doctorale structurate şi } \\
\text { bine definite care includ şi } \\
\text { consilierea şi ghidarea în carieră, } \\
\text { inclusiv pentru cea de cercetare } \\
\text { - Conform Procesului Bologna, a } \\
\text { fost inclus în învăăănântul superior } \\
\text { şi ciclul } 4 \text { sau stagiul post } \\
\text { doctoral (existent, de altfel, în } \\
\text { SUA încă din } 1919 \text { prin programul } \\
\text { „National Research Feelowship } \\
\text { Program“ de către National } \\
\text { Research Council, prin intermediul } \\
\text { Fundaţiei Rockefeller } \\
\text { - Reforma învătămaantului superior }\end{array}$ & $\begin{array}{l}\text { - Studii doctorale mai concentrate în } \\
\text { anumite centre puternice de cercetare } \\
\text { şi mai focusate pe teme actuale de } \\
\text { interes pentru societatea cunoaşterii } \\
\text { - Reducerea şi uniformizarea } \\
\text { duratei medii a studiilor de la } \\
\text { admitere la obținerea titlului de } \\
\text { doctor (3-4 ani full time) } \\
\text { - Adoptarea practicilor de } \\
\text { supervizare multiplă (tutoriat sau } \\
\text { co-tutoriat/co-tutelă) cu supervizori } \\
\text { din instituţii diferite şi dezvoltarea } \\
\text { continuă a abilităţilor profesionale a } \\
\text { cadrelor didactice (conducători, } \\
\text { evaluatori, supervizori de doctorat) } \\
\text { - În condiţiile multitudinii şi } \\
\text { diversificării doctoratelor şi sub } \\
\text { imperativul calității este nevoie de } \\
\text { oferirea de servicii şi facilități } \\
\text { oferite studenţilor (planuri de } \\
\text { dezvoltare personală pentru } \\
\text { candidații la doctorat - ca formă de } \\
\text { ghidare a carierei, monitorizarea } \\
\text { pattern-urilor de carieră ale } \\
\text { absolvenţilor - ca instrumente de } \\
\text { analiză a eficienței şi relevanţei } \\
\text { ofertei educaţionale (tracking } \\
\text { mechanisms), utilizarea unui } \\
\text { Research Student Log. } \\
\text { http://www.ucl.ac.uk/) - ca } \\
\text { instrument de evaluare a calităţii } \\
\text { programelor oferite, folosirea unei } \\
\text { platforme web pentru studenți - ca }\end{array}$ \\
\hline
\end{tabular}


presupune continuarea şi armonizarea între cicluri (studii de licență, master, doctorat, post doctorat)

- Realizarea unei noi „culturi a reglementării'‘ (o educaţie şi o pregătire pentru cercetare mai structurată prin programe disciplinare interdisciplinare sau prin şcoli graduale" (B. Kehm, 2004)

- Cooperare şi competitie (, tition") la nivelul studiilor doctorale în contextul mobilității internaţionale generate de noile structuri Bologna (schimburi intre profesori şi studenți, consorții şi reţele bazate pe proximitate geografică şi tematică, grade comune acordate de una sau mai multe universităţi din diferite țări, internaționalizarea doctoratului şi Doctoratul Europaeus etc.)

- Monitorizarea şi controlul calităţii programelor şi componentelor de cercetare şi adaptarea lor la nevoile studentului şi ale pieţii

- Accent pe dimensiunea socială a accesului la educația doctorală și eliminarea discriminării pe considerente de rasă, clasă, etnie, gen, status social, dizabilitate, vârstă etc.

- Promovarea programelor şi studiilor doctorale la nivel național şi international un instrument de comunicare între candidaţi şi supervizori, între candidați și comunitatea ştiinţifică (http://www.juru.fi/en/) etc.

- Conferirea unor atributii intercorelate doctorandului: student, cercetător, angajat

- Multidisciplinaritate interdisciplinaritate transdiciplinaritate în educația doctorală

- Accent pe dezvoltarea prin studiile doctorale a abilităţilor transferabile: invățare și perfecţionare continuă (life long learning), comunicare academică, abilitąți antreprenoriale, capacitate de lucru în echipă etc.

- Utilizarea de metode de predare şi cercetare creative, moderne, flexibile, adaptate profilului doctoratului şi cerinţelor pieții

$\mathrm{Au}$ fost concepute şi testate noi forme de doctorat (doctorat de cercetare, doctorat profesional, doctorat industrial, doctorat in educaţie, doctorat ca urmare a unor publicaţii), noi programe de studii doctorale, diverse formule de finanţare, noi modalitătii de evaluare sau noi forme de cooperare. 
Conceptul de „Şcoală doctorală” în România, gândit după modelul din SUA, se referă la o comunitate de profesori şi studenți doctoranzi, implicafi în activităţi didactice şi de cercetare pe un domeniu de interes, producând învățare prin cercetare; acest concept a fost instituit în România prin Hotărârea de Guvern nr. 567 din 2005, în care, însă, nu apare explicit, ea stipulând instituirea „programelor de studii universitare“ (partea didacticã) şi a „programelor de cercetare" (partea de cercetare), în cadrul unei Instituţii Organizatoare de Studii Universitare de Doctorat (IOSUD) şi stabilind condiţiile organizării studiilor universitare de doctorat din România în "Școlii doctorale“.

Aspectul cel mai important, care rezultă din ,principiile de la Salzburg“ privind doctoratul european, din Comunicatul de la Bergen, din documentele EUA, care s-au cristalizat şi în constituirea la nivel continental a unui „Council for Doctoral Education", dar şi din politicile naţionale referitoare la doctorat, inclusiv în România, rezidă în inițierea unor reforme de amploare ale sistemelor doctorale.

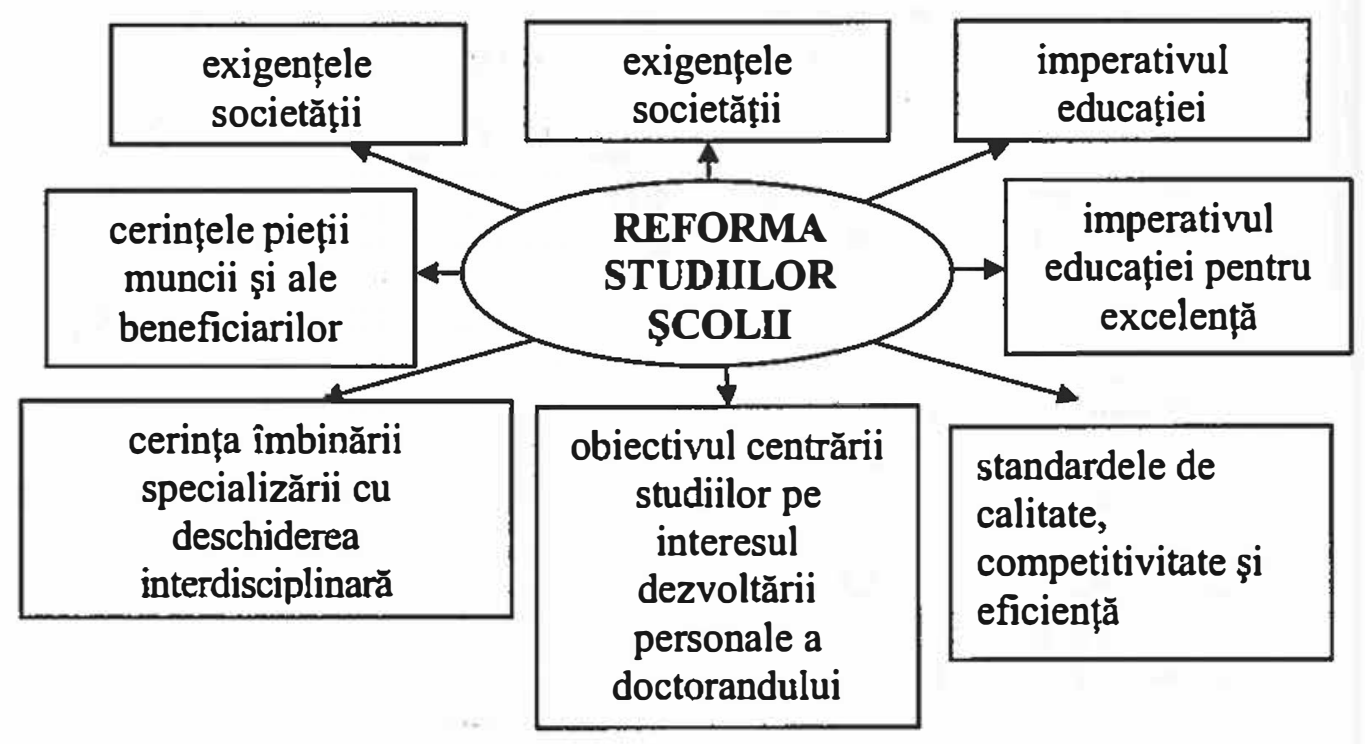

Paradigma actuală asupra studiilor doctorale accentuează dimensiunea socială a acestora, centrarea lor pe multidisciplinaritate, interdisciplinaritate, transdiciplinaritate, pe dezvoltarea de abilităti competitive şi transferabile, pe învăţare şi perfecţionare continuă, pe comunicare interpersonală, pe dezvoltarea de programe de colaborare creative, flexibile, adaptate opțiunii şi profilului doctorandului, precum şi cerințelor pieții muncii, necesităţii fluxului de cercetători şi deschiderii internaţionale.

Trebuie remarcată, de asemenea, emergența unei diversități de tipuri de doctorat: doctoratul tradiţional (traditional phd), doctoratul prin publicare ( $\mathrm{PhD}$ by publication), doctoratul de rutã nouă (new route $\mathrm{PhD}$ ), doctoratul 
profesional (professional doctorate), doctoratul de cercetare $(\mathrm{PhD})$, doctoratul in educație (EdD), doctoratul bazat pe practică (practice-based doctorate), toate contribuind la corelarea studiilor academice cu cercetarea şi cu aplicaţia practică şi stimulând astfel mobilitatea ocupaţională.

În conformitate cu Agenda Lisabona privind învăţământul superior, doctoratul are la bază învățarea prin cercetare şi parteneriatul în domeniul metodologiei şi al conţinutului cercetării ştiinţifice, materializat in calitatea Tezei de Doctorat.

Teza de doctorat reprezintā, în egală măsură, un „vârf" între producţiile ştiinţifice, un document bogat în informaţii originale, un demers academic și de cercetare, pentru obținerea unui grad postuniversitar superior.

În unele studii apărute în ultimul timp, consacrate analizei şi reformårii Şcolii Doctorale, se vorbeşte, însă, de un ,paradox al doctoratului actual“, în sensul că, deşi numărul doctoranzilor, al doctorilor tineri, al programelor disciplinare şi interdisciplinare de doctorat, al universităţilor acreditate sả confere doctorate şi al tipurilor de doctorate este in creştere continuă, se accentuează şi controversele, ambiguitătile sau incertitudinile ,academice“ privind modul de organizare, obiectivele, modalitățile de finalizare specifice doctoratului, precum şi cele referitoare la criteriile şi modul de evaluare a Tezei de Doctorat.

Din astfel de raţiuni, În cadrul Proiectului POSDRU „Inovarea şi dezvoltarea curriculei doctorale din perspectiva formării şi evaluării competenţelor de cercetare; corelaţii cu mecanisme de asigurare a calității" (Contract: POSDRU/1.5/21/G/36046), am intreprins o serie de demersuri de cercetare, atât în scopul unei "diagnoze" a modului de elaborare şi evaluare a Tezelor de Doctorat, cât şi în scop practic, în sensul conceperii şi validării unor criterii de evaluare a Tezelor de doctorat.

\section{Câteva concluzii ale cercetării}

- Nu există diferenţe majore şi semnificative între modul de evaluare a tezei de doctorat în universitățile din spaţiul european şi cel extraeuropean, inclusiv din SUA; diferențele constau în modul mai analitic sau mai puțin analitic de evaluare, în numărul mai mare sau mai mic de criterii avute în vedere.

- În multe universități se aplică aceleaşi criterii de evaluare pentru teza de doctorat și pentru dizertaţie (uneori, teza de doctorat este numită disertaţie).

- Majoritatea universitătilor valorizează pozitiv criteriile de evaluare APA, pe care le folosesc, fie ad literam, fie le adaptează (modificările fiind neesenţiale, sub aspectul conținutului, dar evidente in ceea ce priveşte ordinea, forma de adaptare la spiritul limbii respective, prin care sunt nuanţate semantic). 
- Criteriile de evaluare sunt particularizate şi in funcţie de tipul cercetării; diferenţe mai evidente apar cu referire la cercetările cantitative / calitative / empirice.

- Evaluarea tezei de doctorat se face:

- pe baza Grilelor de evaluare, care cuprind un număr destul de mare de itemi / coordonate ale tezei (referitoare la aspecte de conţinut, formale, de tehnoredactare, de stil lingvistic); evaluarea pe baza grilei se face:

- pe o scală cu 5 calificative:

- slab, mediocru, bine, excelent, inaplicabil / nu se evaluează, pe baza cărora membrii comisiei acordă note pentru fiecare item (Universitatea din Pittsburgh, Pennsylvania, U.S.A., Kwangiu National University of Education, Republic of Korea)

- respins -1 , satisfăcător -2 , bine -3 , foarte bine 4, excelent - 5 (Universitatea din Jiväshylä, Finlanda)

- evaluarea pe o scală în 7 trepte (de la 1 - sărac/slab la 7 - remarcabil ) a criteriilor de evaluare APA adaptate (Universitatea din Michigan, USA)

- pe baza unor calificative: laudatur, eximia cum laude aprobatur, magna cum laude aprobatur, um laude aprobatur, lubenter aprobatur, aprobatur, improbatur, cu specificarea criteriilor de calitate ce trebuie indeplinite (Şcoala din Finlanda).

- pe baza unor criterii de evaluare, care, in majoritatea cazurilor, sunt cvasi identice cu secvențele structurii tezei, care apar şi în Cuprins (Universitatea din Sussex, Marea Britanie). 
Evaluarea preliminare a criteriilor de evaluare a Tezelor de Doctorat, selectate şi sistematizate pe baza tuturor concluziilor demersurilor de cercetare

- Evaluarea fiecărui criteriu din Grila de evaluare a Tezei de Doctorat - cu note de la 1 - 5, în funcţie de relevanța şi importanța pe care fiecare membru din echipa de implementare a proiectului consideră că o are criteriul pentru asigurarea calitătii tezei.

- Evaluarea fiecărui criteriu din sinteza prezentată (universităti străine) - cu note de la $\mathbf{1}-\mathbf{5}$, in functie de relevanţa şi importanța pe care fiecare membru din echipa de implementare a proiectului consideră că o are criteriul pentru asigurarea calităţii tezei.

- Observaţie: Dacă s-a acordat aceeaşi notă mai multor criterii, cum, de altfel, este firesc, s-a specificat şi ordinea în care criteriul va fi inclus, in funcţie de prioritatea lui în ansamblul evaluảrii (de exemplu: nota5/1, nota $3 / 2$ etc.). 


\section{GRILĂ DE EVALUARE A TEZEI DE DOCTORAT}

(propunere pentru dezbaterea echipei de implementare a proiectului)

\begin{tabular}{|c|c|c|c|c|c|}
\hline \multirow{2}{*}{$\begin{array}{l}\text { CATEGORII CRITERIALE, CRITERII ŞI } \\
\text { INDICATORI }\end{array}$} & \multicolumn{5}{|c|}{ SCALA DE EVALUARE } \\
\hline & 1 & 2 & 3 & 4 & 5 \\
\hline \multicolumn{6}{|l|}{$\begin{array}{l}\text { LEGITIMITATEA ŞI OPORTUNITATEA TEMEI } \\
\text { DE CERCETARE ŞI A FINALITĂTII SALE }\end{array}$} \\
\hline \multicolumn{6}{|l|}{$\begin{array}{l}\text { - înțelegerea sistematică şi comprehensivă a } \\
\text { domeniului de studiu }\end{array}$} \\
\hline \multicolumn{6}{|l|}{$\begin{array}{l}\text { - motivația obiectivă (interes ştiinţific, actualitatea şi } \\
\text { necesitatea abordării teoretico-metodologice şi } \\
\text { aplicative, contribuție la progresul cunoaşterii prin } \\
\text { cercetare originală, cu impact naţional sau internaţional, } \\
\text { popularizarea concluziilor valoroase ale cercetării } \\
\text { personale prin publicatii, cărți, studii teoretice şi } \\
\text { aplicative, comanda socială - motivarea utilității } \\
\text { cercetării prin beneficiile pe care le obține populația } \\
\text { (intă, in cazul unei cercetări realizate pe bază de proiect } \\
\text { de cercetare etc.) }\end{array}$} \\
\hline \multicolumn{6}{|l|}{$\begin{array}{l}\text { - motivația subiectivă a alegerii temei (experienfa } \\
\text { practică personală in domeniu, interes particular pentru } \\
\text { problema cercetată etc.) }\end{array}$} \\
\hline \multicolumn{6}{|l|}{$\begin{array}{l}\text { prezentarea clară a problemei studiate, menţionånd } \\
\text { importanfa problemei cercetate din punct de vedere } \\
\text { știintific, economic, social etc., scopul cercetării } \\
\text { (descriere, explicare, control, previziune etc.), } \\
\text { beneficiarii cercetării etc. }\end{array}$} \\
\hline \multicolumn{6}{|l|}{ - actualitatea, noutatea, relevanţa temei abordate } \\
\hline \multicolumn{6}{|l|}{$\begin{array}{l}\text { prezentarea, intr-un stil clar şi sobru, a ideilor, a } \\
\text { punctelor de vedere personale, inclusiv critice, dar } \\
\text { argumentate, in mod separat fałă de ideile preluate din } \\
\text { unele surse bibliografice }\end{array}$} \\
\hline $\begin{array}{l}\text { - concluzii relevante din literatura studiată, din } \\
\text { lucrări/cercetări anterioare legate de temă, cu } \\
\text { mentionarea corectă a autorilor, precum și puncte de } \\
\text { vedere originale referitoare la acestea, păreri personale, } \\
\text { pro sau contra, sustinute cu argumente pertinente }\end{array}$ & & & & & \\
\hline $\begin{array}{l}\text { - prezentarea succintă și relevantă a structurii tezei } \\
\text { (numărul de capitole şi continutul concret, prezentat } \\
\text { succint, tipul de cercetare, obiectivul principal, premise } \\
\text { teoretice, populația-țintă şi eşantionul, perioada de } \\
\text { realizare, metodologia, relevanta cercetãrii) }\end{array}$ & & & & & \\
\hline
\end{tabular}




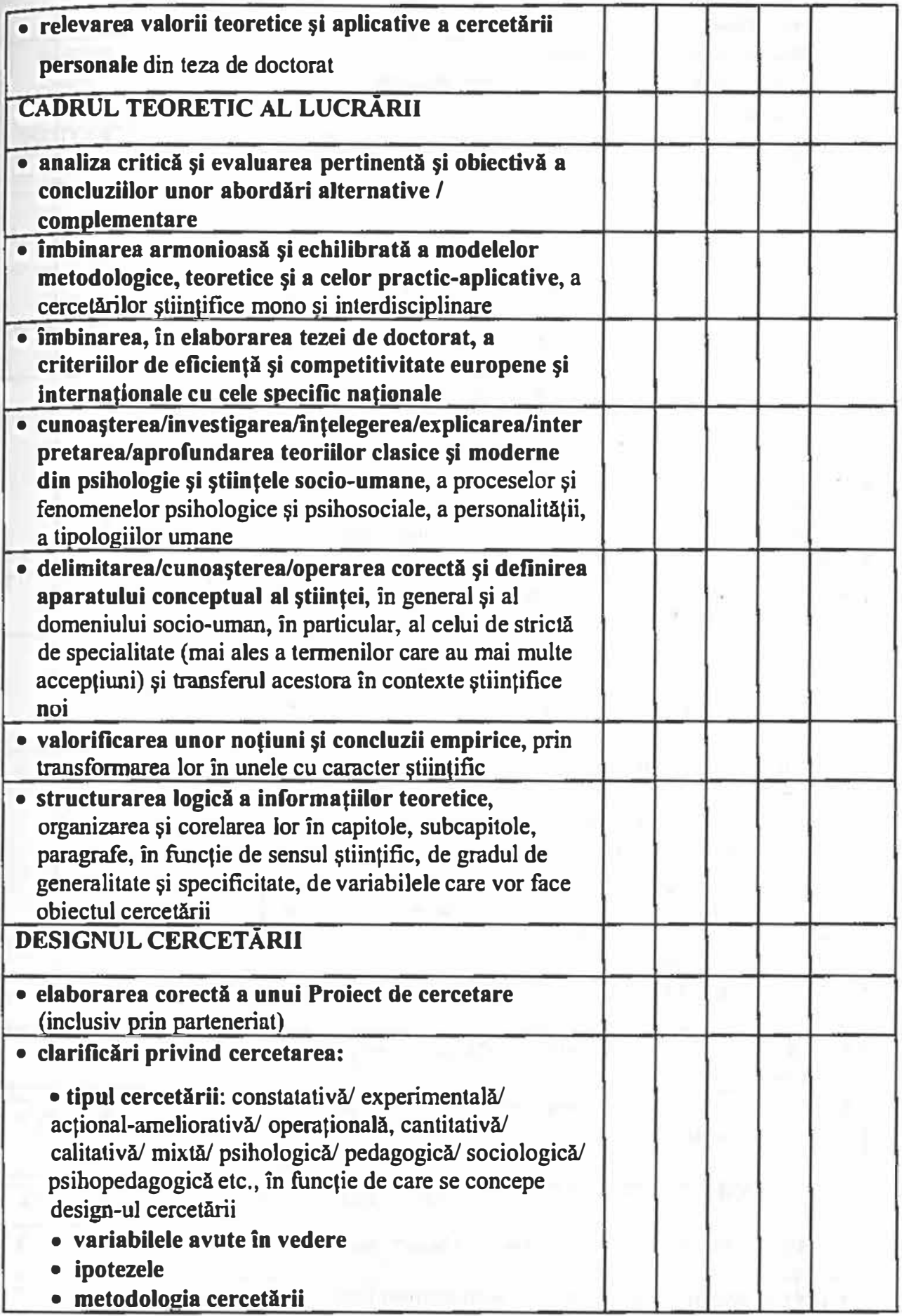




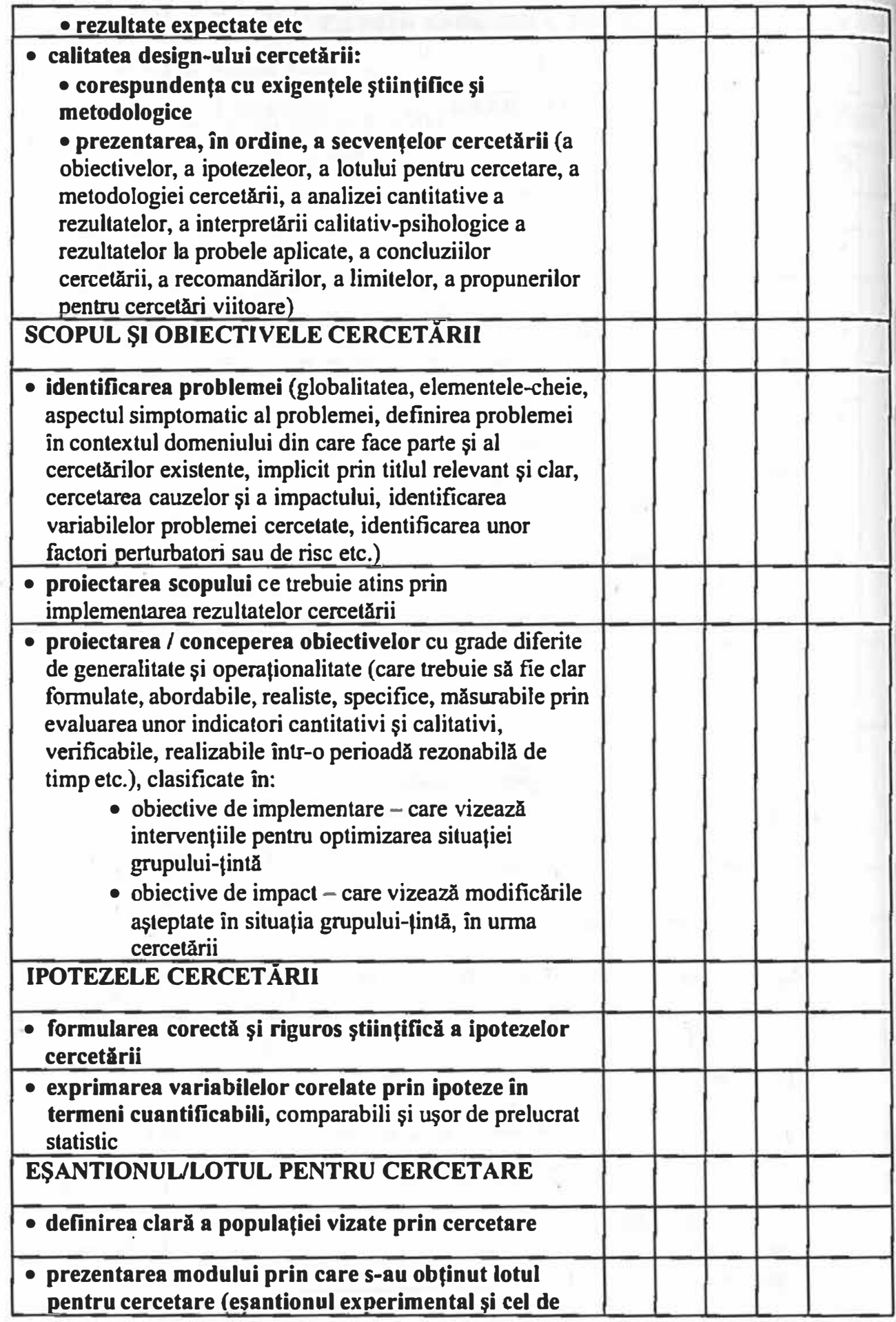


control), modul şi criteriile de selecţie, tipul de eşantionare (criteriile, mårimea, structura, caracteristici, gradul de reprezentativitate pentru populaţia cercelării), modul de participare și atitudinile subiectilor etc.

\section{METODOLOGIA CERCETÃRII}

- selecţia metodelor pentru cercetare adecvate domeniului și specificului cercetării

- modul de utilizare, aplicare, prelucrare, interpretare şi corelare corectă şi multilaterală a probelor şi metodelor pentru cercetare

- descrierea metodelor şi instrumentelor utilizate, după unele criterii:

- gradul de adecvare in functie de specificul problemei cercetate

- måsura in care sunt corect selectate pentru verificarea ipotezelor cercetårii

- modul facil / laborios de aplicare, costul, gradul de necesitate şi pertinentă al informa(iilor ce se pot obpine

- conditiile experimentale in care sunt utilizate şi aplicate (loc, timp, durată, mod individual/colectiv, in mediul natural/artificial, cu limită de timp/cu timp nelimitat, direct/ prin operator, limitele de incredere etc.)

- modul in care sunt prelucrate rezultatele

- prezentarea clară a metodologiei, cu descrierea succintă, dar concludentả a fiecărei metode sau instrument folosit:

- denumire / autor / surså / anul apariţiei / variante / interval de vârstă pentru care se aplicã / grad de validitate / probe concurente / limite etc.

- structura (scale / dimensiuni / itemi / factori etc.)

- scopul (ce evalueazå)

- modul de aplicare / prelucrare / prezentare a rezultatelor

- prezentarea detaliatå a probei/probelor originale, concepute in scopul cercetării

- gradul de corectitudine a realizårii protocoalelor de evaluare

ANALIZA CANTITATIVĂ, PRELUCRAREA ŞI EVALUAREA REZULTATELOR CERCETĂRII

- analiza cantitativã/statisticã, prelucrarea rezultatelor cercetării pe baza programelor statistice adecvate de 


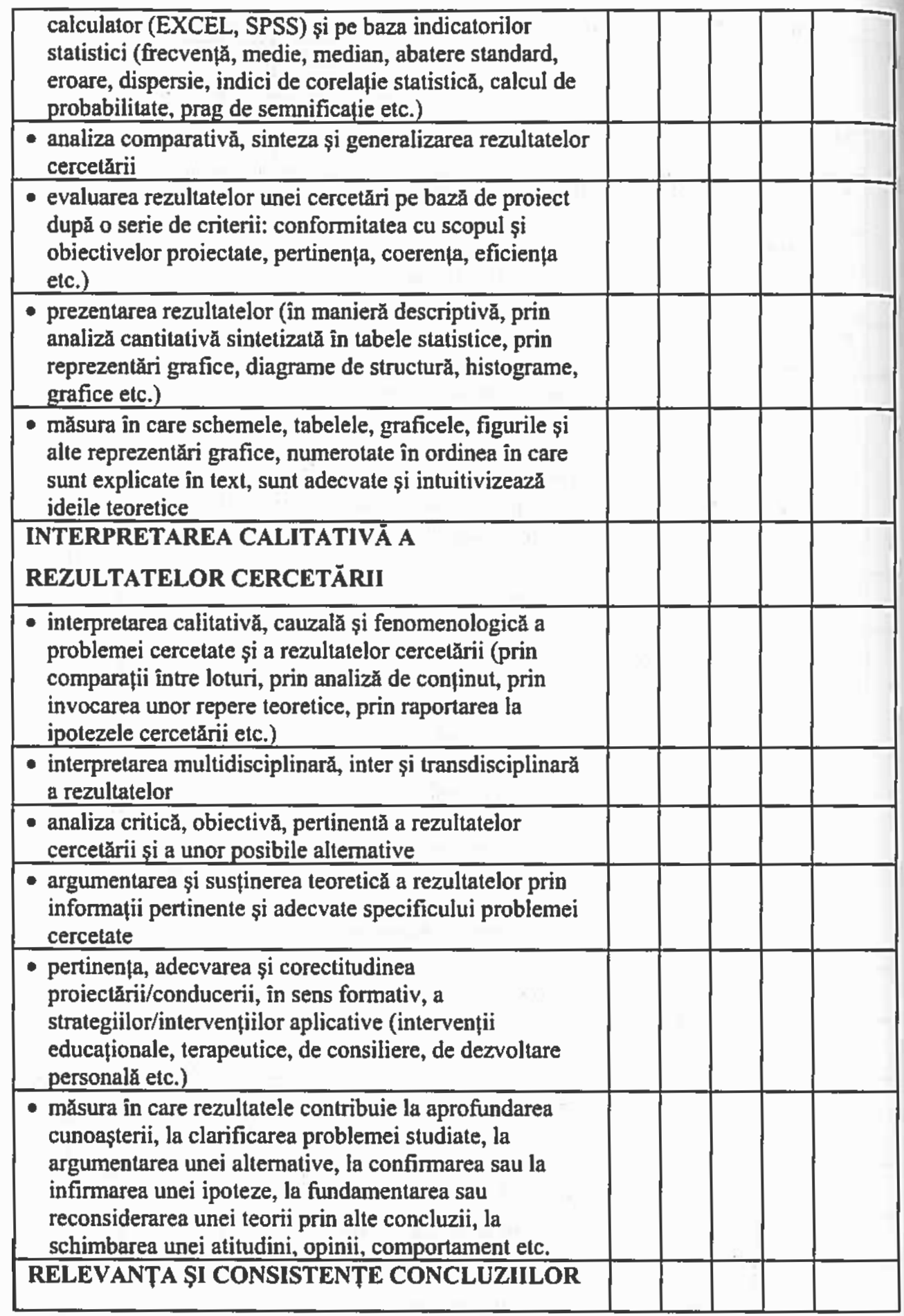


- modul şi posibilitatea de aplicare şi implementare a rezultatelor cercetări (rezultatele trebuie sã fie cunoscute, credibile, diseminate, întelese, acceptate

- gradul in care rezultatele pot determina, prin utilitatea lor, efectele proiectate prin obiective

- masura in care se evidenţiază unele atitudini pozitive şi responsabile fậa de đomeniul ştiințific, dorinta de continuare a cercetării şi a propriei dezvoltări profesionaje, atitudini corespunzătoare deontologiei profesiei

- măsura în care se evidențiază dorința de angajare in relałii de parteneriate ştiinţifice (prin relaționare, comunicare, muncă in echipă interdisciplinară), in perspectiva continuării și aprofundării cercetării personale

- prezentarea, in forme diverse, a unor concluzii clare şi a unor propuneri concrete pentru cercetări viitoare, care să fie uşor de verificat, de înteles, de transformat in ipoteze pentru alți cercetători din domeniul propriu sau din domenii interdisciplinare, precum și uşor de inf̧eles și de utilizat de către beneficiari

- pertinența propunerilor şi recomandărilor

\section{ALTE RIGORI ALE TEZEI DE DOCTORAT}

- bibliografia să fie numerotată în ordine alfabetică şi prezentată după rigorile ştiintifice

- teza trebuie să cuprindă un număr rezonabil de anexe, cu informatii adecvate şi prezentate in mod clar și intuitiv; fiecare anexă trebuie să cuprindã legenda (explicații privind denumirea variabilelor reprezentate, valorile acestora, unitățile de măsură etc.) şi să fie corelată cu tabelul corespunzãtor cu datele cantitative (dacă anexa cuprinde reprezentări grafice)

- titlul trebuie să fie exprimat clar și să conţină 6-12 cuvinte semnificative pentru a surprinde şi evidenția continutul teoretic și esența cercetării

- 3 - 5 cuvinte-cheie - relevante şi definitorii pentru problema studiată

- rezumatul, compus din 100 - 150 de cuvinte, trebuie să cuprindă ideile esențiale 


\section{BIBLIOGRAFIE}

1. California State University (2005). Psychology Thesis Guidelines. http://www.csulb.edu.

2. George Mason University (2004). Psychology Writing Guide. http://www.gmu.edu.

3. Eco, U. (2006). Cum se face o tezã de licentă. Iaşi: Ed. Polirom.

4. Ecole Pratique des Hautes Etudes. Ghid de redactare si de prezentare a Tezei de doctorat.

5. Grünberg, L., Andreescu, L., Hâncean, M.G. (2009). Tendinte actuale in educatia doctorală. București.

6. Mărgineanu, C. (1999) Rigorile unei lucrări ştiintifice. Cluj-Napoca: Imprimeria „Atlas-Clusium”.

7. Radu, I. (2008). Cum se scrie un text ştiintific. Iaşi: Ed. Polirom.

8. Universitatea Babes-Bolyay, Catedra de psihologie (2004). Ghid de redactare a tezei de licentă si masterat. www.psihologie.ro

9. Unversitatea din Bucureşti/Facultatea de Psihologie şi Ştiintele Educației/Specializarea Psihologie. (2006). Ghid de realizare a tezei de licentá şi a disertatiei de masterat

10. Villanova University (2004). A Guide to the Writing of the Master's Thesis. http://www.gradartsci.vjllanova.edu

11. Wayne State University (2004). Format guidelines for preparing theses and dissertations. http://www.gradschool.wayne.edu.

12. http://www.wih.harvard.edu/psych/ug/Thesis/VI.Allport.htm, Gordon W., 2005.

Allport,

13. http://www.cnaa.acad.md. Ghidul privind perfectarea tezelor de doctorat si a autoreferatelor.

14. http://www. fpse.ro. Ghid de realizare a tezei de licență şi a dizertaţiei de masterat.

15. http://www.wesleyan.edu/css/main/thesis guide.html. University, Thesis guidelines, (2004). 